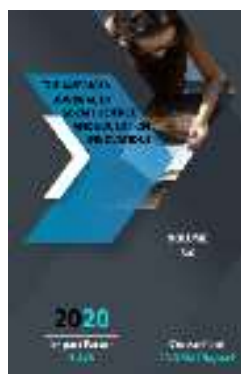

\title{
Introduction To Social Norms That Is Implemented In The Process Of Greetings For Primary School Students
}

\author{
Maryambibi Djumaniyazovna Abdullaeva \\ Lecturer Of Department “Preschool Education”, Chirchik State Pedagogical Institute, \\ Tashkent Region, Uzbekistan
}

\begin{abstract}
Journal Website: http://usajournalshub.c om/index,php/tajssei

Copyright: Original content from this work may be used under the terms of the creative commons attributes 4.0 licence.
\end{abstract}

\section{ABSTRACT}

In this article, the issue of introducing social norms that should be followed in the process of greeting students in the primary education system of Uzbekistan is examined. The international study of the custom of greeting for all peoples and its importance in the world community, in particular, the peculiarities of this custom in the Uzbek nation, the state of scientific and social research will be analyzed. The topic will discuss verbal units of greeting, gestures, as well as prohibited situations in the process. In the process of harmonious teaching and upbringing, special attention is paid to the habit of greeting in primary school, so the importance of correct and timely formation of this habit is emphasized.

\section{KEYWORDS}

Harmony of education and upbringing, gestures, greetings are not allowed, greetings, social norms.

\section{INTRODUCTION}

The custom of greeting is common to all peoples and reflects the characteristics of the people as well as the nation. Greetings help people develop certain social norms. Therefore, the units of vision and greeting are studied as social norms, and special attention is paid in the primary school to the custom of greeting in the process of harmonious education and upbringing of the Uzbek nation. There are also a number of studies on the custom of greeting internationally. This article examines the issue of introducing social norms 
that should be followed in the process of greeting students in the primary education system of Uzbekistan. The topic will include greeting units, gestures, as well as prohibitions in the process.

Greetings play an important role in social relations between people. Greeting, which is a form of interaction between social subjects and is the initial stage of the interaction process, also serves to express the state of mind between two people. Greetings are also social in nature, as they are organized according to certain norms and ethical requirements. In this way, in the process of greeting, one can get information about a person's etiquette, spirituality, worldview, and level of cultural formation.

Sheikh Muhammad Sadiq Muhammad Yusuf comments on this: "If you want to meet a stranger, greet him and he will start talking, and the alienation and discomfort will disappear. Even if you say "Assalamu alaykum" (peace be upon you) to your opponent, he will get angry, the cake will disappear, and his heart will lean towards you. The blessings of greeting, the rewards for it, overwhelm everyone"'.

Because it is reflected in the basis of social relations, each social group of people (people, nation, ethnicity, tribe, and even clan) has long since formed certain requirements for the organization of the process of greeting. According to the norms formed by different peoples, nations, peoples, tribes, and clans, the process of greeting is expressed through certain words and gestures (mostly hand gestures). Greeting norms (requirements) are usually formed on the basis of the ethnopsychology, lifestyle, aspirations of a

\footnotetext{
${ }^{1}$ Sheikh Muhammad Sadiq Muhammad Yusuf. Social etiquette. www.islom.uz. 2019

${ }^{2}$ Hadith - for children. - Tashkent: "Adolat", 2004. - 15p

${ }^{3}$ Pedagogika tarixi / Pedagogika oliy o'quv yurtlari va dorilfununlar talabalari uchun o'quv
}

particular social group (people, nation, ethnicity, tribe, and clan), the values that are important to them. Although the process of greeting takes place differently in different social groups, all of these processes have served the same purpose - to establish mutual friendship, peace, and brotherhood between people. It is narrated in a hadith: "Greet one another. Then love will awaken in you"

The social value of greetings is highly valued because of the importance that human relationships play in the development of good ideas. Accordingly, in different nations, one of the most important educational tasks is to acquaint the younger generation with the essence of the process of greeting and to teach them to greet properly. In pedagogical works, too, attention is paid to the elucidation of the rules (norms, requirements) of greeting. In particular, in the work of Muhammad Sadiq Qashqari, who lived in the XVIII century and the first half of the XIX century, entitled "Etiquette as-salihin" ("Etiquette of good people"), along with various forms of social relations, people the requirements for greetings are also mentioned. According to the author, "If two believers come first, whether they are acquaintances or strangers, they will greet you. It is sunnah to greet them, and the answer is obligatory" That is if the greeting is an action that must be performed, then responding to the greeting is an action that must be performed by Muslims.

The rules of greeting in the novel are as follows:

- Older (old man) to younger;

- On horseback (now the driver of the vehicle) on foot;

- To a pedestrian to seated;

qo'llanma[History of Pedagogy / A textbook for students of pedagogical universities and medical schools]. K. Hoshimov va boshq. Toshkent: O'qituvchi, 1996. - 235-bet 
- Few to many (a small number of people to a large number of people);

- Anyone who enters the room must greet those sitting here.

Even today, greetings are seen as an important process of communication between social subjects and the simplest form of personal etiquette. Greetings also have their own sociopsychological characteristics. "The behavior, character, upbringing, inner feelings, mood of the respondents at that time, and their attitude to the viewer, the person who greeted them, and the difference between them are obvious." Therefore, the requirements for greeting young people in the family and in educational institutions - it is necessary to acquaint them with social norms, to teach them to greet properly, to form in them the skills of adaptation to social relations.

The following tasks are pedagogically effective in introducing students to the rules of etiquette in the primary grades:

1) Highlight the social and personal significance of greeting to students;

2) Explain the meaning of "Assalamu alaykum", "Salom" and other words and phrases used in greeting;

3) To inform students about the conditions under which words and phrases such as "Assalam-u alaykum", "Salom" and their alternatives are used, as well as greetings are not allowed;

4) Ensure that students have a clear understanding that greeting people is a positive event;

5) Provide students with information about the meaning of facial, head, body, and hand movements used in greeting;

6) To develop students' ability to greet family members, adults, and peers.

Quyida o'quvchilarni salomlashishga oid ijtimoiy me'yorlar bilan tanishtirish borasida belgilangan vazifalarni bajarish jarayoni to'g'risida so'z yuritiladi.
The process of completing the tasks set to introduce students to the social norms of greeting is following.

\section{To highlight the social and personal significance of greetings.}

The social and personal significance of greetings can be demonstrated through conversations and question-and-answer sessions with students. Students will be asked the following questions:

a) "Why do we greet each other?".

b) "What if people don't greet each other??".

c) "Do you like to be greeted by your peers?".

d) "What do you think: is it necessary to greet those around you every day?".

e) "What do you think will happen if we don't greet each other??".

In the course of lessons or spiritualenlightenment activities, it is possible to show respect to others by greeting students, to share joy with people, to express good wishes, to show kindness as a result of mutual greetings, friendship, and peace. attention is paid to explaining the installation. During the lessons, students realize that if people do not greet each other, there will be mutual mistrust, lack of affection, inconvenience, and it is a sign of politeness to greet each other not only every day but every time.

It is important to emphasize that greeting student is a fun event for everyone.

\section{To help students understand that greeting is a positive, good, noble event.}

Once elementary students understand the social and personal (private) importance of greetings to people, practical efforts are made to reinforce the understanding of the subject. Students' attitudes toward greetings are explored through conversations, questions, and answers, and the telling of short stories based on the actions of various fairy tale or cartoon characters. Here are some short stories and questions for students: 
A. One day Carlson forgot to say hello when he met Mittivoy. When Mittivoy asked him why he didn't greet him, Carlson said, "Did I greet you yesterday?" Why should I say hello every time we meet. I don't think it's possible to say hello once and then for the rest of your life." he replied.

Tell me, is Carlson right??

B. "You, don't hurry!", "Something can change my bad behavior," Wolf told Rabbit in the cartoon. Let the wild beasts greet me every time they meet me. I really like this. Only then will I not oppress others." Guys, tell me, if a forest animal gets used to greeting a wolf, will it not hurt those around it?

C. One bright summer day, the beavers turned to Uncle Kunduz and said, "Uncle, we had an argument. Help us to solve this problem: should we greet each other once a day or every time we meet?"

Guys, what do you think, Uncle Kunduz, how should he answer this question?

3. To cover the meaning of "Assalamu alaykum", "Salom" and other words and phrases used in greeting.

When primary school students are introduced to the meaning of "Assalamu alaykum," "Salom," and other words and phrases used in greeting, they will better understand the social significance of greeting. In this process, the teacher not only uses words such as "Assalomu alaykum" and "Salom" to greet the students but also "Xayrli tong", "Xayrli kun", "Xayrli kech", "Xayrli tun", “Hormang! " should also provide information on the use of expressions such as The teacher can use the following dictionary to explain the meaning of words and phrases used in greetings during lessons and spiritual and educational activities:

- Assalomu alaykum - Peace be upon you!; I wish you peace and prosperity!

- Salom - Peace, and security to you!

- Xayrli tong - Have a good morning

- Xayrli kun - Have a nice day

- Xayrli kech - Have a nice evening
- Xayrli tun - Have a good night

- Hormang! - Don't get tired of what you are doing!

During the lesson or spiritual-educational work, the teacher is required to remind students of the need to pronounce the phrase "Assalam-u alaykum" correctly and completely. Because young people have a habit of using this phrase in the wrong way. That is, some young people say "Somalaykum" when they greet others. In Arabic, the word "som" means "death". Therefore, by saying "Somalaykum", "I wish you death!" they don't even realize what they're trying to do.

\section{To provide students with information about the meaning of facial expressions, body language, and hand gestures.}

Almost all peoples have a habit of using not only speech but also various gestures, such as facial expressions, head, body, and hand gestures, to show that people greet each other with kindness. is produced. At the same time, facial expressions, body language, and hand gestures have a special meaning. Here is a brief description of them.

1) The fact that the face is open when greeting means that people who greet each other are happy to see each other, respect each other, or love each other (meaning: "I am very happy to see you"), "I was so glad to see you");

2) a slight bowing of the head during a greeting - a special respect for each other by those who greet each other (meaning: "I respect you, so I bow before you!");

3) a slight bowing of the body in the process of greeting, a bowing - means that the respect of the people greeting each other is infinite (meaning: "I respect you too much, so I bow before your feet!" );

4) handshakes when greeting each other - a sign of friendship (meaning: "My hand is empty, it has no weapons!"); 
5) Raising the right hand and opening the palm of the hand during the salutation means that the people greeting each other are not enemies and therefore do not have weapons in their hands (meaning: "I am not an enemy to you, so "I don't have a weapon");

6) The addition of the right hand to the left breast during the greeting signifies that the people greeting each other love each other from the heart (meaning: "I love you from the bottom of my heart", "I love you from the bottom of my heart". "raman ");

7) hugging when greeting - means that the people greeting each other love each other very much, miss each other (meaning: "I will always miss you because I love you so much"; I miss you so much ");

8) clapping on each other's shoulders during greetings - mutual greetings of people greeting each other; such greetings are usually given by the elderly (meaning: "I thank you for your kind words");

9) a kiss on the forehead of the greeter during the greeting process means that the person receiving the greeting is happy that the person greeting the person is healthy and wishes him well, so greetings are usually given by older people. (meaning: "Thank you, may your head always be safe!").

5. Develop students' ability to greet family members, adults, and peers.

The following is prohibited during the greeting:

- To abbreviate or distort the phrase "Assalamu alaykum.";

- If the conversation is in Uzbek, then use greeting phrases in foreign languages (words like "Privet", "Hello", "Chao", "Salute", "Okay");

- Use the phrase "Salom berdik";

\footnotetext{
${ }^{4}$ Uzakov I. A. Boshlang'ich sinf o'quvchilarida mas'uliyat hissini shakllantirishning pedagogik asoslari[Pedagogical bases of formation of a
}

- Dark face (feeling dissatisfied with something);

- Greeting just, not really;

- Clench your fists;

- Shake hands;

- Hold one's hand for a long time;

- Shake hands with girls or adults until they reach out;

- Put your hand on your stomach;

- pronunciation of words too loudly, not sufficiently clear;

- Kissing (as far as possible, relatives, parents and children, brothers and sisters should not kiss and greet each other in accordance with the requirements of hygiene);

- Shake hands while eating;

- Shake hands with everyone when you're late for an event;

- Ask aloud for condolences;

- People greet each other in the cemetery;

- Greetings in bathrooms and toilets.

When introducing elementary students to the greeting rules, they should be reminded to greet them as they enter the room through the door.

\section{CONCLUSION}

Thus, greeting is the beginning of social relations. During the greeting process, friendly and benevolent relations are established between the social actors. From time immemorial, different nations have developed their own rules of greeting[4] $]^{4}$. Familiarizing young people, including primary school students, with the rules of greeting will help them to adapt effectively to social life. During the greeting, students develop positive emotions that will help them grow into a fullfledged person.

sense of responsibility in primary school students]. T-2008 
With that in mind, it's a good idea to introduce elementary school students to the rules of greeting.

\section{REFERENCES}

1. Masharipova U.A. "Methods of forming the speech culture of primary school students in the context of innovative education", Written dissertation for the degree of Doctor of Philosophy in Pedagogical Sciences. Tashkent. 2018.

2. Vohidova N.X. "Fostering national pride in primary school students based on folklore". T-2011

3. Maksadova M.S. Psychological features of the professional training of future primary school teachers. T-2011

4. Uzakov I. A. "Pedagogical bases of formation of a sense of responsibility in primary school students". T-2008.

5. Mirziyotov I. M. "Pedagogical bases of formation of healthy beliefs in primary school students (on the example of improving the content of the subject "Etiquette" on the basis of national values)" T-2008.

6. Sheikh Muhammad Sadiq Muhammad Yusuf. Social etiquette. www.islom.uz. 2019.

7. Abdumannotov A. M. "Formation of spiritual concepts of primary school students on the basis of Alisher Navoi's legacy (on the example of the epic "Hayrat ul-abror")" T-2004

8. Wolff, P. H., Gardner, J., Paccia, J., \& Lappen, J. (1989). The greeting behavior of fragile $X$ males. American Journal on Mental Retardation, 93(4), 406-411.

9. Goffman, E. (1971) Relations in public. NewYork: Basic Books. Google Scholar

10. Separation of gestures and the regressive connection of expressive movements. Leonhard K.Psychiatr Neurol Med Psychol (Leipz). 1973 Apr; 25(4):199-207.
11. Morris, D. (1977) Manwatching: Field guide to human behavior. New York: Abrams. 